\title{
Single cell transcriptome analysis upon MCF-7 breast cancer
}

\author{
Yih-Shien Chiang ${ }^{*}$, Lock Ying Seng, You-Yu Lin, Shih-Hao Chen, Yu-Chang Su, Tzu-Han Chen, Hong-Chih Kuo, \\ Chung-Hsuan Chen, Kuo Ping Chiu
}

From Beyond the Genome: The true gene count, human evolution and disease genomics

Boston, MA, USA. 11-13 October 2010

\section{Background}

During cancer progression, the genome and epigenome of each cancer cell mutate constantly, leading to a diverse transcriptome in a cancer tissue. Such diversity results in variations in drug response among individual cancer cells and is responsible for poor prognosis. It is therefore important to reveal the diversity in the transcriptome profiles of single cancer cells, in order to further understand how the diversified cancer cells interplay to make a cancer cell population capable of escaping immune surveillance and respond poorly to drug treatment.

\section{Materials and methods}

Here, we adopt the recently published single cell transcriptome (SCT) analysis protocol and evaluate its reliability using RNA- seq approach on analysis of housekeeping (HK) gene expression as a control, and describe four SCT libraries and one 5,000-cell transcriptome library generated from MCF-7 breast cancer cells.

\section{Results}

The SCT libraries and the 5000-cell library mapped to $11,534,12,053,10,805,12,533$, and 13,032 known genes, respectively. Among the four SCT libraries, there were $61-85 \%$ and $76-91 \%$ overlaps at the exon and gene levels, respectively. Moreover, out of 143 HK genes previously selected by two independent groups, 140 were found to be consistently expressed and 1 was unexpressed in all five libraries, whereas the other $2 \mathrm{HK}$ genes were expressed only in some single cells, suggesting a high sensitivity and reproducibility of the SCT approach.

\footnotetext{
Genomics Research Center, 128 Academia Road, Sec. 2, Nankang District,
} Taipei 115, Taiwan

\section{Conclusions}

Comparison between genes constitutively expressed in all libraries $(14,429)$ and genes differentially expressed only in some libraries $(7,068)$ revealed that most of the differentially expressed genes are either extracellular proteins, or proteins involved in synaptic activities or metabolism. Taken together, our data demonstrate a high degree of reproducibility of SCT analysis and suggest a plausible 'collaboration' between cancer cells on secretion, nerve development and metabolism.

Published: 11 October 2010

doi:10.1186/gb-2010-11-S1-P8

Cite this article as: Chiang et al:: Single cell transcriptome analysis upon MCF-7 breast cancer. Genome Biology 2010 11(Suppl 1):P8.

\author{
Submit your next manuscript to BioMed Central \\ and take full advantage of: \\ - Convenient online submission \\ - Thorough peer review \\ - No space constraints or color figure charges \\ - Immediate publication on acceptance \\ - Inclusion in PubMed, CAS, Scopus and Google Scholar \\ - Research which is freely available for redistribution \\ Submit your manuscript at \\ www.biomedcentral.com/submit
}

